\title{
ARAŞTIRMA MAKALESİ/RESEARCH ARTICLE \\ RELIGIOUS TREATMENT AND PREVENTING FOR COVID-19 (CASE OF INDONESIAN MUSLIM COMMUNITY IN MANAGING COVID-19 PANDEMY)
}

\author{
Muhammad TAQIYUDDIN \\ PhD Student, Aqidah and Islamic Philosophy, Universitas Darussalam Gontor Ponorogo Indonesia \\ taqiyuddin@unida.gontor.ac.id \\ orcid.org/0000-0002-0797-9181 \\ https://ror.org/029tp8j70
}

\begin{abstract}
Despite the communities in the world have different strategies about Covid-19 treatment, some countries still sociologically rely on religious treatment. This is also the salient feature of religious communities in Indonesia with Muslim majority. In fact, his attitude also varied; but has a meeting point that can be studied with the integrated perspective of science and religion. This mixed method research model uses historical qualitative data from scientific articles and non-survey quantitative data; which collecting the both cultural and structural official statements that can be traced its circulation in the community through social media. By the statements, its refer from religious authority as well as indonesian 'kiai' or mass organization, also the religious educational institution. Trought fenomenological approach, his study at least concluded that the majority of the Indonesian Muslim community responded to Covid-19 moderately. Although, at least their attitude is divided into 3 groups: a) ordinary people, b) scientists, c) religious. But in general, they can articulate and collaborate in facing the Covid-19 with a harmonious alignment between religious tradition, science and technology. Evidenced by the emergence of regulations and graphic design products and social agreements that projected the values of Islamic teachings, science and technology as well.
\end{abstract}

Key Words: Covid-19, Indonesian Muslim, Religious Treatment, Islamic Worldview

\section{DINII TEDAVI VE COVID-19'U ÖNLEME (COVID-19 PANDEMISI'NI YÖNETMEDE ENDONEZYA MÜSLÜMAN TOPLULUĞU ÖRNEĞİ)}

Öz

Covid-19 tedavisi hakkında Dünya'nın her tarafında farklı yöntemler bulunmaktadır. Buna rağmen bazı ülkeler sosyolojik bakımdan hâlâ dini tedavi yöntemine güvenmektedir. Bu durum Endonezya'daki Müslüman çoğunluğa sahip dini topluluğun göze çarpan bir özelliğidir. Aslında Endonezya'nın tutumu bu konuda çeşitlidir. İçinde bulundurduğu anlayış pozitif bilimlerin ve dinin bütünleşik perspektifiyle incelenebilecek bir buluşma noktasına sahiptir. Bu karma araştırma modeli, bilimsel makalelerden alınan tarihsel nitel verileri ile anket dışı nicel verileri kullanır. Böylece sosyal medya aracıllğıyla toplumdaki sirkülasyonu takip edebilen hem kültürel hem de yapısal resmi söylemleri toplayan bir kuruluştur. Bu söylemlerle, dini otoritenin yanı sıra aynı zamanda 
dini eğitim kurumu anlamında gelen Endonezya 'kiai' veya kitle örgütüne atıf yapar. Fenomenolojik yaklaşım kullanılarak Endonezya'nın bu durumu en azından Müslüman nüfusunun çoğunluğunun Covid-19'a 1lımlı olarak yanıt verdiği sonucuna ulaştı. Bu toplumun tutumu ise üçe ayrılmıştır: a) sıradan insanlar, b) bilim adamları, c) dindarlar. Ancak genel olarak Covid-19 ile yüzleşirken dini gelenek, bilim ve teknoloji arasında uyumlu bir şekilde kendilerini ifade edip iş birliği yapma olanakları vardır. İslami öğretilerin yanında bilimin ve teknolojinin de değerlerini yansıtan düzenlemeler, grafik tasarım ürünleri ve sosyal anlaşmaların belirmesiyle bu durum gözler önünde kanıtlanmıştır.

Anahtar Kelimeler: Covid-19, Indonesian Muslim, Religious Treatment, Islamic Worldview.

Atıf / Cite as: Taqiyuddin, Muhammad. "Religious Treatment and Preventing for Covid-19 (Case of Indonesian Muslim Community in Managing Covid-19 Pandemy)”: Apjir 5/3 (Aralık 2021), 493-508.

\section{Introduction}

Specifically, among the problems that were fixed by religion and its authority; is disaster management. As a developing country; disaster management really needs synergy from all parties. Not to mention, the level of technological readiness and public knowledge is not entirely able to be used. Thus, sometimes religious leaders as the people's mobilizing authority, may not be able to determine the right attitude because of the lack of scientific competence; due to various reasons.(Joakim and White 2015) This is the key to the urgency of the synergy. Resources that cannot yet be owned by religious authorities and religious leaders, can be supplied by the government as stakeholders in the country.

The government as an executive can legitimize legal authority and regulations to support the creation of such synergy. The government really needs religious institutions with their authority; affiliated with CSOs in carrying out mitigations to other actions. Islamic religious leaders, both in school areas and community organizations; also contributes to preventive action. This includes aspects of non-structural disaster mitigation; but has quite a broad impact.(Adiyoso and Kanegae 2013) In fact, the success of this method can overcome and anticipate social and political conflicts between organizations. That is, this method can be used to deal with disasters; as long as it is supported by regulations and reliable resources. Including scientific and technological assistance.(Sindre 2018)

This research uses a combination of qualitative and quantitative method (mixed method).(Turpin, Asano, and Finlayson 2015; Baškarada and Koronios 2018) The objects are phenomenon of Indonesia Muslim societies in facing Covid-19. Data collected through tracking literature samples in the form of: 1) circulars and appeals from religious organizations at the community and state institutions such as ministries and others.(Taqiyuddin 2020b) 2) poster or designs contained info related to the Muslim community in facing Covid-19.(Taqiyuddin 2020a) 3) scientific works: journals, theses, dissertations. The data was analized historically and critically descriptive; and tracing the roots of the religious attitude of the Indonesian Muslim community. Then compare it with documented social facts in various online news.(Taqiyuddin 2020c) 
Moreover, this disaster is global pandemic. As we face these days; namely the emergence of the Corona Novel virus (NCov) or scientifically called Corona Disease 2019 or COVID19. The spread of the virus preliminary reported from Wuhan, China. Namely, starting from the fish market mixed with other animals. The virus originally known from this animal, eventually transmitted to humans. In China, the varian of Corona virus are HCoV229E, HCoV-OC43, SARS-CoV, HCoV-NL63, HCoV-HKU1, and MERS-CoV. The Institute for Disease Management in China (the Chinese Center for Disease Control and Prevention) found various samples in the wild animal market; by swabbing the organs in animals such as blood, stomach and throat.(Stein 2020; Brüssow 2020; Stratton 2020) As of December 2019, the spread in China continued more massive during the Chinese New Year; where the mass are gathering in large scale. And then transferring among human body unconsciousness. Until January 31, 2020; This epidemic has spread to 19 countries with 11,791 confirmed cases and 213 deaths. This prompted WHO to declare a Public Health Hazard.(Adhikari et al. 2020)

The hiypotheses taken by the researchers such:

1. This virus originates from wild animals that are consumed, thus infecting humans.

2. This virus transmitted through human contact; as well as droplets, liquid that comes out of coughing and sneezing that spreads into the air and attaches to various surrounding objects.

3. Viruses attached to various objects transmit to humans through the touch of a hand on droplet objects. The virus-containing hand is in contact with the respiratory tract; so the virus can enter the respiratory tract.

For this reason, world scientists recommend the government to conduct population lockdown and patients isolation as long as the vaccine had not be founded. The spread was through social contact such as a handshake, kissing, to cuddle with the 'carrier of the virus'.(Salzberger, Glück, and Ehrenstein 2020; Stein 2020)

Some countries that have large Muslim communities have taken action.Religious institutions and authorities began to play a role. In Saudi Arabia, the government has closed access to tawaf at night. The closure of Umrah access was also carried out; as a preventive measure before the outbreak due to the absence of social distancing in the worship. Based on government experience, the potential spread of outbreaks in this area will be quite high. Because the daily spreading of influenza and respiratory diseases can reach 50\%; dominated by 50 years and over.(Ahmed and Memish 2020; Ebrahim and Memish 2020) In addition, in Indonesia and several other countries, similar policies have been carried out in Saudi Arabia are limiting the hajj quota. In fact, some countries have clearly canceled Hajj for 2020 (1442).

\section{Religiosity in Indonesia: Background and Role}


Religious society is a typical culture of Indonesia. This is based on Pancasila, which is in the first principle; it is mentioned about 'Oneness of God'. That is, even though Indonesia is not a particular religious state, religion is a value that is accommodated in Indonesian law. In fact, the religion is bureaucraticly posites as the ministry of religion. Religion has also become an inseparable part of the dynamics and traditions of the people in the Indonesian public sphere. So, under any circumstances and however; will still involve religious institutions in it.(Latif 2018; Abdullah 2017)

This constitution enables religious plurality in Indonesia. All religions coexist peacefully with strong legislation. Religion, too, can be a solution to the socio-cultural problems that sometimes occur.(Kumar 2017) Although of course, there are parts that can be easily resolved; some are complicated enough to solve. In broad outline, religious patterns in Indonesia can be considered as Muslim majority represent moderate Islam. This is in line with the method of Islamization in this archipelago; through the bi-l-hāl da'wa path, also mauidzah hasanah. So, gradually; religion is a part of political power in Indonesia.(Zarkasyi 2008; Ahyar and Alfitri 2019)

Religion in Indonesia always appears to be a 'guardian' in the community. Also as a medium for the spread of wise harmony between Indonesian citizens; even in the arena of international diplomacy. Religion is also an ethos of thinking that underlies the emergence of culture, local wisdom, and tradition and intellectual ethos. (Hosen 2017) That is, religion and its laws become part of the authority that helps regulate the sociocultural order in Indonesia; such as marriage law or religious community. The authoritative figures are participating in resolving the problem in public spaces; through official statements in certain religious fields and religious institutions.(Makin 2018; Hasyim 2015)

The religious legitimacy, historically can be traced from the scientific tradition that developed in Indonesia itself. Recorded a number of Nusantara scholars at that time which recognized internationally. In fact, his various works written in Arabic, which in that time become world Muslim academic language. With such religious capacity, it certainly had an influence in shaping the culture of the Nusantara Muslim community at that time, even today.(Syahnan 2019)

In the next period, the religious leaders joined hands with nationalists in liberating Indonesia from foreign colonialism. In fact, the scholars also fought and led the national movement at that time in various ways. KH Hasyim Asy'ari, for example, helped to take up arms while at the same time proclaiming jihad against the invaders as martyrs. As well as the economic and educational movement that is also produced by $\mathrm{KH}$ Ahmad Dahlan Muhammadiyah organization. That is, all these figures launched a political nationalism based on Islamic teachings.(Syamsuddin 1995; Zarkasyi 2019; Kusmana 2019) 
However, the condition of religiosity in Indonesia is quite good and conducive. Especially before the influx of globalization and ideology from outside Indonesia. It can be seen, that the political and social atmosphere of Indonesia remains religious with its various moderate attitudes. Except, in some cases academically as well as methodologically polarized political elites and public figures; that is, influenced by foreign frameworks or Orientalist studies in stigmatizing several Islamic streams that have actually been peaceful in their plurality.(Buaben 2017; Montgomery and Heathershaw 2016) This is evidenced by the efforts of some academics who position the opposite between religion and science. It also stigmatizes that Islam has roots that foster purist, fundamentalist and even extremist terrorist attitudes. Of course, such an effort called an expression of hatred for the Islamic community in Indonesia, which is on average moderate.(Aguilera-Carnerero and Azeez 2016; Arat-Koç 2014; O'Donnell 2018)

However, in this pandemic era; Islamic cultural entities in Indonesia have proven their ability to organize society especially in facing this pandemic. In fact, its effectiveness exceeds the ability of academics, political elites, or public figures mentioned above. This figured by various mass dan political organizations and other community organizations that play a large role in the community. This role seems to have helped academics, political elites and public figures who were in the position of policy holders to collaborate in handling this national disaster.(Rajab, Nurdin, and Mubarak 2020; Zahrotunnimah 2020; Mahmuddin and Syandri 2020)

An interesting fact is that in Indonesia there has been an institutionalization of religious authority by maintaining the plurality of schools and Muslim organizations. The institutionalization is inseparable from the academic world; namely the existence of Islamic universities as well as Islamic schools at the level of childhood to high school. If in the era of the struggle for independence of tradition by the Indonesian Ulema Council nationally, also continued by various other Islamic organizations.(Hasan Basri 2020; Darmawan et al. 2020)

This is because of the basic understanding of moderate Muslims from various elements of the organization regarding the relationship between Islam and disaster. Namely, their ability to see comprehensively about pandemic issues from the point of view of religious thought that is inseparable from scientific methodology. Also an integrated wisdom acts that representing the teachings of Islam.(Novanda 2020; Machendrawaty et al. 2020; Mansyur 2020) This will be explained briefly about the view of the relationship between Islam and the scientific phenomenon in the form of the Covid-19 disaster.

\section{Religiosity and Disasters}

Historically, Islam has also affirmed that disasters have a background or a particular cause. These causes and effects referred to as phenomena or signs that must be 'read' through scientific methodology. In Islam, using scientific methodology is not much 
different from the scientific methodology known in this modern era. This is because Islam also affirms that the five senses and ratios are an inseparable part of the epistemology of Islam. This clarifies the position of Islam in viewing causality as part of God's power that can reasoned technically through reason and five senses. (Zarkasyi 2018)

What distinguishes, that Islam affirms the God as metaphysical Cause behind the phenomenon of cause and effect that appears in the physical world. More than that, Islam affirms the power of God who 'created' the natural law. This characteristic is what causes the Islamic worldview (Islamic Worldview) to have a broad spectrum in viewing nature, humans, and other metaphysical matters. This view forms a kind of cultural matrix that is inherent in a variety of social to scientific activities of a Muslim.(Abdullah, M. and Nadvi 2011; Ishaq and Daud 2017)

This view of life does not stop at the level of belief or belief alone. In Islam, the concept of faith has a relationship between beliefs, words and deeds at the same time. We can observe this in the pillars of faith and the pillars of Islam. Which, if we examine each of its aspects, strongly reflects the universality of Islam as a teaching of life. The concept of faith is very much tied to the implementation of Islamic teachings called the Shari'a. Which, is a comprehensive rule of life as a value system, law, ethics and aesthetics both individually and communally. All aspects of sharia are inseparable from the element of 'intention', which is part of the theological affirmation of the purpose of the implementation of sharia, namely worship of God.(Daud 2015; Majid and Haliding 2014; Hassan 2018)

So, even though physically looks the same human, both Muslims and infidels. For example, chicken that is slaughtered Islam is not much different physically from that which is slaughtered is not Islamic. The difference is in the aspect of lafadz basmalah as sharia and theological affirmation of the purpose of slaughtering chickens, namely getting halal food to support the survival of worship for God. In the context of the Covid19 pandemic it is also no different. Muslims can follow health protocol made by nonMuslims though. This is because in the Shari'a there is a command to 'hifdz al nafs' (safeguarding the soul - survival) and a prohibition to plunge oneself into danger.(Dahlan et al. 2020) Such religious orders are included in the category of Islamic maqasid. Moreover, if the scientific research (especially medical) found that such disasters bring serious harm and danger, where danger can be threatening if the association held a mass gathering.(Auda 2007; Kamali 2019; Alyanak 2020)

In general, community religiosity proved to play an active role in helping disaster management. The evidence arises when the social movement of the community in fundraising is driven by community organizations such as Muhammadiyah, Nahdhatul Ulama, and others. Organizations such as political parties also carry religious motivation in justifying the truth of their actions to help deal with disasters. The motivation, the 
movement is a step that has the dimension of pious charity and amar ma'ruf (commanding good /right) as well as rewarding in the sight of Allah.(Joakim and White 2015; Rokib 2012) On the scale of religious knowledge, disaster management is categorized in contemporary fiqh, often called Disaster Fiqh. Which, some aspects of the law will be adjusted to the needs; without changing the essence of the pillars of Islam itself. (Ha 2015; Iskandar 2019)

The Covid-19 phenomenon can explained scientifically without contradicting religion. Scientists and religious authorities have confirmed that viruses seen as living organisms that are so small that they are invisible. The life of the virus proved to have a cycle that follows 'sunnatullah' (God's laws), which has a part of character that is permanent and unchanging. In fact, its life cycle can predicted and understood scientifically. This explanation, although most come from non-Muslim scientists, but the results can used for Muslim communities anywhere.(Hasbiyallah et al. 2020)

In Indonesia in particular, religious leaders also mobilized their abilities through their capacity as leaders of CSOs and other organizations; both large and small in guarding the safety of Muslims in their respective congregations. This is marked by the emergence of various religious fatwas about the implementation of religious activities in mosques, schools, and the wider community. Globally, this phenomenon has actually happened in the international Islamic world.(Ahmed and Memish 2020; Dahlan et al. 2020; Hasbiyallah et al. 2020; Rusyana et al. 2020)

There are several religious fatwa from community organizations, universities, and others that issued statements about Covid-19. In general, we can map it into several clusters. Namely: fatwa on the implementation of worship in public places, fatwa on the implementation of religious activities based on local culture, and fatwas that are motivating the Muslim community in dealing with the Covid-19 disaster. This represent the emergence of fatwas about obligatory prayers and Friday prayers based on the Islamic fatwa approach, to fatwas relating to how to address Covid-19 in the view of Islamic creed.(Qotadah 2020b; Rajab, Nurdin, and Mubarak 2020; Mahmuddin and Syandri 2020; Djalante et al. 2020)

All ijtihad ulama products about religious fatwas about Covid-19, can be categorized as scientific activities that have roots in Islamic intellectual traditions. Even in the perspective of the philosophy of science, we cancall this fatwa a product of science; which emerged from the Islamic scientific methodology called ijtihad.(Javed and Javed 2015) We can say this, because the process of ijtihad is very laden with methodology and scientific activity in concluding an Islamic law in the form of a fatwa. This scientific activity based on religious assumptions that built based on the Qur'an and hadith as a theoretical foundation in viewing the Covid-19 phenomenon.(Muslih 2016; 2019) 


\section{Mapping Indonesian Muslim Community}

Islam sees the plague as another disease. However, the terms used to refer to this are quite diverse. Various groups also have their own ways. For example, if we divide by several stages, especially in terms of access to academic literacy:1) the civilian, 2) scientists, and 3) religionists.(Muslih 2017) In this case, the civilian represents people who have followed more scientific, social and political discourse than created it; although of course, people always have social agreements and local wisdom which we can call indigenous science.(Hiwasaki et al. 2014; Davids 2016)

If traced, in fact the community often gets guidance from figures; in the Indonesian context, that the majority of Muslim communities are bound by certain Islamic figures. Factually, the community often bases its actions based on the guidelines of these figures. This explains the emergence of some traditions with customary and cultural dimensions that have Islamic nuances. Although the shape is varied; both verbally using Islamic symbols and local customs that do not conflict with Islam.(Irfan 2017; Nadhiroh 2018; Irbansyah 2019; Putra 2018; Khoiri 2017)

Meanwhile, scientists represent people who are involved in certain scientific fields, both to obtain academic degrees or not. In his hierarchy, scientists also have diverse competencies. Both mastering disciplines that are linear or interdisciplinary, multidisciplinary, and interdisciplinary. Thus, all of his attitudes also reflect thoughts, products, to different ideas and views in seeing the Covid-19 phenomenon.(Hasyim 2015; Zarkasyi 2019; Musadad 2015) In Indonesia for example; almost all scientists in it represent the community based on religious values in Pancasila. Thus, the technicalities and steps in dealing with Covid are also different from those of other countries. This proven by the writing of various scientific works that have religious dimensions and relate them to the Covid-19 disesase.(Saefi et al. 2020) These religious-based scientific works had written by students and lecturers in Islamic and public universities.

The scientist complexity views on Covid-19, is also experienced by people who are categorized as religious in the community. They act as direct enlighteners and guides of the community; often, they called ulama, kiai, or others. With their scientific capacity, they become a source and reference for the community when certain problems are encountered. Also with their capacity, they are collaborated with the government in pandemic prevention measures on a national scale. Among them is the collaboration of the government and MUI in providing direction in the dimensions of scientific, religious, also related to public policy in order to provide social order in the pandemic.(Rusyana et al. 2020; Junaedi et al., n.d.; Mansyur 2020; Kuipers, Mujani, and Pepinsky 2020)

\section{Preventive Action of the Indonesian Muslim Community during Covid-19}

Based on the mapping above, we can conclude the existence of convergence among these groups. In particular, the integrative aspect that links the Covid-19 phenomenon with 
Islam and science at the same time. What is interesting is that various preventive solutions for the Muslim community in Indonesia have certain characteristics. Which, his various actions reflect religious and social motivations which also proved scientific in dealing with the Covid-19 phenomenon. These things can be proven by the existence of several regulations which also have national and international standards, but have a justification from religious arguments :

1. The Social Distancing as regulation that restricts social activities or prohibits a mass gathering at a place. Usually, religious rites in Islam; which has both a spiritual and a social dimension; often requires the implementation of worship carried out simultaneously (in congregation).(Qotadah 2020b) With the Covid-19, a problem arose: how to hold congregation prayer at the mosque? Especially about the every Muslim's obligation of Friday prayer. This was clearly addressed by religious authorities by issuing fatwas about Friday prayers during the pandemic.(Kuipers, Mujani, and Pepinsky 2020) Following the prayer in congregation in the mosque and attending walimatul 'ursy, until the resignation of the pilgrimage this year (due to the absence of istithā'ah ).(Rajab, Nurdin, and Mubarak 2020; Hasbiyallah et al. 2020; Mushodiq and Imron 2020; Mansyur 2020; Maravia 2020)

Some of the practices can be witnessed in various news stories on social media; from electronic newspapers to certain social media accounts. Here are also various guidelines about congregational prayer with physical distancing. Until the implementation of Eid al-Fitr.(Taqiyuddin 2020c; 2020b; 2020a) The keywords used as a reason to stop the law from the obligations at the top are related to an emergency situation; that is, promoting the maqāshid syarīah and sad dzariah.(Hidayatullah and Nasrullah 2020) Called emergency, because there are primary things that must be prioritized by the sharia, namely the safety of the soul and aqidah at the same time. Which, both relies on personal safety first.(Al Amin 2020; Hasibuan and Yusram 2020; Arsad 2020; Rusyana et al. 2020; Hasbiyallah et al. 2020)

2. Closing the nose when sneezing and mouth when coughing. That this case is, in fact, the teaching of Islam; and it has been implemented since Covid-19 has not spread though. This is because of the Rasululullah hadith related to the ethics of sneezing and coughing; which he always puts his hand or cloth on his face to close it and reduce his voice.(Helmi Basri 2018; Arifin et al. 2020; Hanbal 2001 vol. 15, p. 412, hadits no. 9662; Al-Sijistaniy, n.d. vol. 4, p. 307, hadits no.5029; Abdusshomad 2020) Internationally, this behavior is highly recommended by any health practitioner. Even at the international level, this acts is recommended by WHO in the health protocol.(Ashraf et al. 2020; Cascella et al. 2020) Because, one aspect of Covid19 transmission is through droplets resulting from sneezing or coughing that spreads open in the air. So, closing your nose when sneezing and coughing is recommended.(Cascella et al. 2020; Islam et al. 2020; Amanambu 2020) For this reason, this has been consciously popularized through religious figures who collaborate with scientists and governments.(Taqiyuddin 2020a) 
3. Ablution and purification are one of the religious orders. Which, at the same time, has scientific benefits in the form of maintaining health and hygiene.("Ablution Wisdom in the View of Quran, Hadith, and Medicine" 2011) If we look at aspects of the pillars and legal requirements of ablution, we will find some scientific matters; for example using clean and purifying water, up to limbs such as face, hands, feet, and even dedicated to rinse and cleanse the nose and ears. These things, certainly very helpful in maintaining cleanliness which is highly recommended in the health protocol.(Rahman 2020; Suhendar et al., n.d.)

Some contemporary problems regarding the obligation to purify as a condition of worship for medical personnel can be answered. That those who take cover behind PPE and are not advised to take it off, are allowed to use waivers (rukhsah) for tayammum.(Qotadah 2020a; Amel 2019; Arsad 2020) Psychologically, performing ablution correctly can increase optimism and calmness. Which, both of these attitudes can help deal with community and individual concerns ; that is, the Muslim community did not experience chaos during the pandemic.(Ilyas 2020)

Social motivation was also promoted in the Covid-19 era. Interestingly, that social motivation is based on the teachings of Sufism in Islam. Which, in the modern way is meant as psychotherapy.(Ahmad Fajar et al. 2020) Its function is to bring the calm of the individual to the community in dealing with the plague. Calmness is needed in formulating appropriate actions and attitudes; especially in organizing social worship activities.(Yono, Rusmana, and Noviyanty 2020; Rifa'i et al. 2020; Hajar 2020) Some forms of activities are dhikr, tadabbur al-Qur'an, online religious lectures, to prayer in congregation at home filled with tausiyah.(Saebani et al. 2020)

The theological awareness above gave birth to a productive religious attitude. Namely patience, resignation, to be pleased with the will of Allah. This kind of attitude was also built in various appeals and circulars spread by Islamic-based organizations and political organizations.(Yono, Rusmana, and Noviyanty 2020; Yono 2020; Daniel 2020) Online and written appeals were also submitted by several religious leaders in the community; both through newspaper and non-newspaper social media.(Taqiyuddin 2020c; Suherdiana et al. 2020)

Collaboration of the Religious Authority with the Government can be interpreted as the alignment of the umara 'and ulama. Its function is to facilitate Muslims in a variety of things that are needed, such as disinfection of mosques, to health protocols for Islamic educational institutions such as pesantren and others.(Rajab, Nurdin, and Mubarak 2020; Daniel 2020) The government really needs to work together with scholars and other religious figures; because social legitimacy is always in their hands, even though the legality of administration is held by the government. This is because religion really regulates the social activities of the community and its culture.(Rusyana et al. 2020; Solahudin et al. 2020) 


\section{Conclusion}

It is an interesting fact that can be concluded, apart from the professionalism in handling the Cov en-19 by the Indonesian government; namely the religious attitude of the Muslim community in Indonesia. Not as expected that religion is often associated with myths, in fact Muslims in Indonesia in their communities are very convergent and integrated with religious and scientific studies; although some are still not socialized. The productive religious attitude factor is because of the easy access of the ummah to Islamic educational institutions such as state and private Islamic tertiary institutions; following tradition Muslims that concerns the authority of the clergy. Further research needed is a detailed mapping of the level of religious awareness in various regions; thus clarifying the influence and contribution of religious organizations and Islamic educational institutions in these locations. 


\section{Reference}

Abdullah, M. and Nadvi, M. “Understanding the Principles of Islamic World-View.” The Dialogue 6/3, (2011), 1-16. http://www.qurtuba.edu.pk/thedialog/.

Abdullah, M. Amin. "Islam as a Cultural Capital in Indonesia and the Malay World: A Convergence of Islamic Studies, Social Sciences and Humanities." Journal of Indonesian Islam. (2017) https://doi.org/10.15642/JIIS.2017.11.2.307-328.

Abdusshomad, Alwazir. "Pengaruh Covid-19 Terhadap Penerapan Pendidikan Karakter Dan Pendidikan Islam." QALAMUNA: Jurnal Pendidikan, Sosial, Dan Agama 12/2: (2020), 107-15.

“Ablution Wisdom in the View of Quran, Hadith, and Medicine.". Arak Medical University Journal. 2011.

Adhikari, Sasmita Poudel, Sha Meng, Yu-Ju Wu, Yu-Ping Mao, Rui-Xue Ye, Qing-Zhi Wang, Chang Sun, et al. "Epidemiology, Causes, Clinical Manifestation and Diagnosis, Prevention and Control of Coronavirus Disease (COVID-19) during the Early Outbreak Period: A Scoping Review." Infectious Diseases of Poverty 9/1, (2020), 29. https://doi.org/10.1186/s40249-020-00646-x.

Adiyoso, Wignyo, and Hidehiko Kanegae. "The Preliminary Study of the Role of Islamic Teaching in the Disaster Risk Reduction (A Qualitative Case Study of Banda Aceh, Indonesia)." Procedia Environmental Sciences. (2013) https://doi.org/10.1016/j.proenv.2013.02.110.

Aguilera-Carnerero, Carmen, and Abdul Halik Azeez. "KEYWORDS Islam Muslims Hate Speech Cyber Islamophobia Twitter Critical Discourse Analysis 'Islamonausea, Not Islamophobia': The Many Faces of Cyber Hate Speech.” Journal of Arab \& Muslim Media Research. 2016. https://doi.org/10.1386/jammr.9.1.21_1.

Ahmad Fajar, Dadang, Isep Zaenal Arifin, Hajir Tajiri, and Elly Marlina. "Membentuk Ketahanan Mental Berbasis Tasawuf Melalui Dzikir Lathifah Sebagai Metode Terapi Terhadap Efek Pandemi Covid 19.” LP2M. (2020).

Ahmed, Qanta A, and Ziad A Memish. "The Cancellation of Mass Gatherings (MGs)? Decision Making in the Time of COVID-19." Travel Medicine and Infectious Disease, 101631. (2020) https://doi.org/https://doi.org/10.1016/j.tmaid.2020.101631.

Ahyar, Muzayyin, and Alfitri Alfitri. "Aksi Bela Islam: Islamic Clicktivism and the New Authority of Religious Propaganda in the Millennial Age in Indonesia." Indonesian Journal of Islam and Muslim Societies 9/1, (2019), 1-29. https://doi.org/10.18326/ijims.v9i1.1-29.

Al-Sijistaniy, Abu Daud Sulaiman bin al-Asy'ats bin Ishaq bin Basyir bin Syadad bin Amru al-Azadiy. n.d. Sunan Abi Dawud. Edited by Muhammad Muhyi al Din Abdul Hamid. Beirut: Maktabah al-'Ashriyyah.

Alyanak, O\uguz. "Faith, Politics and the COVID-19 Pandemic: The Turkish Response." Medical Anthropology. 2020. Https://Doi. Org/10.1080/01459740.2020 1745482.

Amanambu, Uchenna Ebony. "Almajirı Islamıc Practıces And The Covid-19 Pandemic In Nigeria: Matters Arısing." Journal of Applied Philosophy 18/3, (2020).

Amel, Camelia Rizka Maulida. "Konsep Rukhsah Bagi Tenaga Medis Dengan Alat Pelindung Diri Saat Menangani Pasien COVID-19." Al-Qanun: Jurnal Pemikiran Dan Pembaharuan Hukum Islam 22/2, (2019), 262-82.

Amin, M Nur Kholis Al. "Menakar Nilai Kemanfaatan Penangguhan Walimat Al-'Ursy Di Masa Darurat CovID-19 Melalui Analisis Sadd Adz-Dzari'ah." Ulumuddin:Jurnal Ilmu-Ilmu Keislaman 10/1, (2020), 27-38.

Arat-Koç, Sedef. "Dance of Orientalisms and Waves of Catastrophes: Culturalism and Pragmatism in Imperial Approaches to Islam and the Middle East." Third World Quarterly. 2014. https://doi.org/10.1080/01436597.2014.971563.

Arifin, Tajul, Neni Nuraeni, Didi Mashudi, and Encang Saefudin. "Proteksi Diri Saat Pandemi CoVID-19 Berdasarkan Hadits Shahih." (2020).

Arsad, Muhammad. "Efektıvitas Rukhshah Dalam Pelaksanaan Ibadah Masa Pandemı Covid-19." Yurisprudentia: Jurnal Hukum Ekonomi 6/1, (2020), 59-74.

Ashraf, Hamid, Ahmad Faraz, Md Raihan, and Sanjay Kalra. "Fighting Pandemics: Inspiration from Islam." JPMA. The Journal of the Pakistan Medical Association 70/5, (2020), S152--S156.

Auda, Jasser. Maqasid Al Shariah as Philosophy of Islamic Law A Systems Approach. Middle-East Journal of Scientific Research. (2007). https://doi.org/10.5829/idosi.mejsr.2013.13.1885. 
Baškarada, Saša, and Andy Koronios. "A Philosophical Discussion of Qualitative, Quantitative, and Mixed Methods Research in Social Science.” Qualitative Research Journal. (2018). https://doi.org/10.1108/QRJ-D17-00042.

Basri, Hasan. "Religious Community Responses to COVID-19: Case Study on Muslim Small Community." International Journal of Psychosocial Rehabilitation 24/8, (2020), 10439-46.

Basri, Helmi. "RELEVANSI ANTARA HADITS DAN SAINS Kaedah Dan Aplikasinya Dalam Bingkai Ijaz Ilmi." AlFikra: Jurnal Ilmiah Keislaman 17/1, (2018), 130-46.

Brüssow, Harald. "The Novel Coronavirus - A Snapshot of Current Knowledge." Microbial Biotechnology n/a (n/a) (2020). https://doi.org/10.1111/1751-7915.13557.

Buaben, Jabal M. "The Middle Path of Moderation in Islam: The Qur'anic Principle of Wasatiyyah / Mohammad Hashim Kamali." Islam and Civilisational Renewal 8/3, (2017), 444-46. https://doi.org/10.12816/0042936.

Cascella, Marco, Michael Rajnik, Arturo Cuomo, Scott C Dulebohn, and Raffaela Di Napoli. "Features, Evaluation and Treatment Coronavirus (COVID-19)." In Statpearls. (2020). [Internet]. StatPearls Publishing.

Dahlan, Moh, M Sirajuddin, Andri Saputra Miinuddin, A Novan Safi?i, and Adella Lovita. "Consistency of Rural Muslim Communities in Maintaining Safety (Hifdz Al-Nafs) in Performing the Worship of Daily Prayers (Shalat) in the Midst of Covid-19 Outbreak." Journal of Talent Development and Excellence 12/1, (2020), 2134-39.

Daniel, Tumpal Daniel Tumpal. "Penguatan Tarbiyah Umat Dan Kontribusi Islam Atasi Covid 19." Alasmal Jurnal Media Informasi Dan Komunikasi Ilmiah 2/1, (2020), 13-22.

Darmawan, Dadang, Deni Miharja, Roro Sri Rejeki Waluyajati, and Erni Isnaeniah. "Sikap Keberagamaan Masyarakat Menghadapi Wabah CoVID-19." Religious: Jurnal Studi Agama-Agama Dan Lintas Budaya 4/2, (2020), 115-24.

Daud, Wan Mohd Nor Wan. "The Metaphysical Worldview." In A Companion to the Worldview of Islam; Course Materials for Wise Summer School 2015. Kuala Lumpur: CASIS-UTM. (2015).

Davids, Nuraan. "Beyond the Indigenous/Non-Indigenous Knowledge Divide: The Case of Muslim Education and Its Attenuation to Cosmopolitanism." South African Journal of Higher Education 28/5, (2016). https://doi.org/10.20853/28-5-410.

Djalante, Riyanti, Jonatan Lassa, Davin Setiamarga, Choirul Mahfud, Aruminingsih Sudjatma, Mochamad Indrawan, Budi Haryanto, et al. "Review and Analysis of Current Responses to COVID-19 in Indonesia: Period of January to March 2020." Progress in Disaster Science, 100091. (2020).

Ebrahim, Shahul H, and Ziad A Memish. "COVID-19: Preparing for Superspreader Potential among Umrah Pilgrims to Saudi Arabia." The Lancet 395/10227, 2020. e48. https://doi.org/10.1016/S01406736(20)30466-9.

Ha, Kyoo Man. "The Role of Religious Beliefs and Institutions in Disaster Management: A Case Study." Religions. (2015). https://doi.org/10.3390/rel6041314.

Hajar, Andi. "Ajaran Al-Mahabbah Sebagaı Upaya Mengatası Keresahan Manusı Dalam Menghadapı Pandemı Covid-19.” Jurnal Al-Qalam: Jurnal Kajian Islam \& Pendidikan 2/1, (2020). 18-29.

Hanbal, Abu 'Abdullah Ahmad bin Muhammad Ibn. Musnad Al-Imam Ahmad Ibn Hanbal Tahqiq Syu'aib Al-Arnauth Wa Abdullah Bin Abdul Muhsin Al-Turkiy. Vol. 14. Beirut: Al-Risalah Foundation. (2001).

Hasbiyallah, Hasbiyallah, Ratu Suntiah, Hilda Ainisyifa, and Titim Fatimah. "Fikih Corona: Studi Pandangan Ulama Indonesia Terhadap Ibadah Dalam Kondisi Darurat Covid-19.” Karya Tulis Islam Fakultas Tarbiyah Jurusan PAI. 2020.

Hassan, Nur Jannah. "The Integration of Qur'anic Worldview with Natural Science: Answering the Long Call For Islamic Secondary Schools." Al-Burhan: Journal of Qur?An And Sunnah Studies 2/1, (2018), 18-34.

Hasyim, Syafiq. "Majelis Ulama Indonesia and Pluralism in Indonesia." Philosophy and Social Criticism. (2015). https://doi.org/10.1177/0191453714566547.

Hidayatullah, Hidayatullah, and Nasrullah Nasrullah.. "Enforcement of Health Law In The Crisis Period of Pandemic Outbreak Covid-19:'The Policy of Large Scale Social Limitation (LSSL) in Indonesia Viewed of the Theory of Al-Maqaashid Asy-Syar'iyyah'." Syariah: Jurnal Hukum Dan Pemikiran 20/1, (2020), 43-58.

Hiwasaki, Lisa, Emmanuel Luna, Syamsidik, and Rajib Shaw. "Process for Integrating Local and Indigenous Knowledge with Science for Hydro-Meteorological Disaster Risk Reduction and Climate Change 
Adaptation in Coastal and Small Island Communities." International Journal of Disaster Risk Reduction 10, (2014), 15-27. https://doi.org/https://doi.org/10.1016/j.ijdrr.2014.07.007.

Hosen, Nadirsyah. "Religion and the Indonesian Constitution: A Recent Debate." In Law and Religion, An Overview. 2017. https://doi.org/10.4324/9781315091990.

Ilyas, Sabrida Muhammad. "Islamic Psychotherapy In The Pandemic Of Covid-19." ENLIGHTEN: Jurnal Bimbingan Konseling Islam 3/1, (2020), 35-47.

Irbansyah, Ricky. "Pandangan Ulama Dan Masyarakat Kecamatan Singkil Kabupaten Aceh Singkil Tentang Adat Temetok Dalam Walimah Al-'Ursy.” Universitas Islam Negeri Sumatera Utara. (2019).

Irfan, Agus. "Local Wisdom Dalam Pemikiran Kyai Sholeh Darat: Telaah Terhadap Kitab Fiqh Majmu'at AlShari'ah Al-Kafiyah Li Al-'Awam." Ulul Albab: Jurnal Studi Dan Penelitian Hukum Islam 1/1, (2017), 88-109.

Ishaq, Usep Mohamad, and Wan Mohd Nor Wan Daud. "Ibn Al-Haytham'S Classification of Knowledge." AlJami'ah 55/1, (2017), 189-210. https://doi.org/10.14421/ajis.2017.551.189-210.

Iskandar, Mizaj. "Fiqh Anticipation: Mitigation Concept Based on Islamic Law." In IOP Conference Series: Earth and Environmental Science. (2019). https://doi.org/10.1088/1755-1315/273/1/012045.

Islam, M Saiful, Kazi M Rahman, Yanni Sun, Mohammed O Qureshi, Ikram Abdi, Abrar A Chughtai, and Holly Seale. "Current Knowledge of COVID-19 and Infection Prevention and Control Strategies in Healthcare Settings: A Global Analysis." Infection Control \& Hospital Epidemiology, (2020), 1-11.

Javed, Arshia, and Muhammad Javed. "The Need of Ijtihad for Sustainable Development in Islam." IIUC Studies, (2015). https://doi.org/10.3329/iiucs.v9i0.24027.

Joakim, Erin P., and Robert S. White. "Exploring the Impact of Religious Beliefs, Leadership, and Networks on Response and Recovery of Disaster-Affected Populations: A Case Study from Indonesia." Journal of Contemporary Religion, (2015). https://doi.org/10.1080/13537903.2015.1025538.

Junaedi, Jujun, Mukhlis Aliyudin, Dede Sutisna, and Prita Priantini Nur Chidayati. n.d. "Konflik Interpretasi Fatwa MUI Dalam Pelaksanaan Ibadah Selama Pandemi Covid-19.” Digital Library UIN Sunan Gunung Djati.

Kamali, Mohammad Hashim. "Maqāṣid Al-Sharī‘ah, Ijtihad and Civilisational Renewal." In Maqasid Al-Shari'ah, Ijtihad and Civilisational Renewal, (2019), 1-46. https://doi.org/10.2307/j.ctvkc6797.4.

Khoiri, Khoiri. "Antara Adat Dan Syarıat (Studi Tentang Tradisi Mandi Safar Di Tasik Nambus, Riau, Ditinjau Dari Perspektif Islam)." Jurnal Ilmiah Islam Futura 16/2, (2017), 196-210.

Kuipers, Nicholas, Saiful Mujani, and Thomas Pepinsky. "Encouraging Indonesians to Pray From Home During the COVID-19 Pandemic." Journal of Experimental Political Science, (2020), 1-11.

Kumar, Gautam. "Indonesian Religious Culture and the Undercurrent." Heritage of Nusantara: International Journal of Religious Literature and Heritage, (2017). https://doi.org/10.31291/hn.v5i2.144.

Kusmana, Kusmana. "The Qur'an, Woman and Nationalism In Indonesia: Ulama Perempuan's Moral Movement." Al-Jami'ah:Journal of Islamic Studies 57/1, (2019), 83-116.

Latif, Yudi. "The Religiosity, Nationality, and Sociality of Pancasila: Toward Pancasila through Soekarno's Way." Studia Islamika, (2018). https://doi.org/10.15408/sdi.v25i2.7502.

Machendrawaty, Nanih, Yuliani Yuliani, Asep Iwan Setiawan, and Yuyun Yuningsih. "Optimalisasi Fungsi Mesjid Di Tengah Pandemic Covid 19: Telaah Syar'i, Regulasi Dan Aplikasi.” UIN Sunan Gunung Djati Bandung. (2020).

Mahmuddin, Ronny, and Syandri Syandri. "Qadariyah, Jabariyah Dan Ahlus Sunnah (Studi Komparatif Merespon Kebijakan Pemerintah Dan Ulama Mencegah Merebaknya Covid-19).” Bustanul Fuqaha: Jurnal Bidang Hukum Islam 1/2, (2020), 209-22.

Majid, Jamaluddin, and Safri Haliding. "The Need for the Islamization of Knowledge in Accounting." Al-Iqtishad: Journal of Islamic Economics. (2014), https://doi.org/10.15408/ijies.v6i1.1366.

Makin, Al. 'Not a Religious State': A Study of Three Indonesian Religious Leaders on the Relation of State and Religion." Indonesia and the Malay World. (2018), https://doi.org/10.1080/13639811.2017.1380279.

Mansyur, Muchtaruddin. "Hajj Health Istithaah amid the COVID-19 Pandemic." Medical Journal of Indonesia 29/2, (2020), 115-17.

Maravia, Usman. "Rationale for Suspending Friday Prayers, Funerary Rites, and Fasting Ramadan during COVID19: An Analysis of the Fatawa Related to the Coronavirus." Ethics 4/2, (2020). 
Montgomery, David W., and John Heathershaw. "Islam, Secularism and Danger: A Reconsideration of the Link between Religiosity, Radicalism and Rebellion in Central Asia." Religion, State and Society. 2016. https://doi.org/10.1080/09637494.2016.1220177.

Musadad, Asep N. “Klasifikasi Ilmu Pengetahuan Dalam Perspektif Jābir Bin Ḥayyān.” Kanz Philosophia: A Journal for Islamic Philosophy and Mysticism 5/2, (2015), 115. https://doi.org/10.20871/kpjipm.v5i2.126.

Mushodiq, Muhamad Agus, and Ali Imron. "Peran Majelis Ulama Indonesia Dalam Mitigasi Pandemi Covid-19 (Tinjauan Tindakan Sosial Dan Dominasi Kekuasaan Max Weber).” SALAM: Jurnal Sosial Dan Budaya Syar-I 7/5, 2020, 403.

Muslih, Mohammad. “Al-Qur'an Dan Lahirnya Sains Teistik.” TSAQAFAH 12/2, (2016). https://doi.org/10.21111/tsaqafah.v12i2.756.

-_-Pengembangan Sains Islam Dalam Perspektif Metodologi Program Riset Lakatosian. Yogyakarta: UIN Sunan Kalijaga Press. (2017)

-_-“Toward Theology of Science: Philosophical Reflection On The Development of Religion-Based Science." KALAM. (2019). https://doi.org/https://doi.org/10.24042/klm.v13i1.3953.

Nadhiroh, Wardatun. “Kitab Sanjata Mu'min: Sebuah Bentuk Tafsir Awam Di Tanah Banjar." SUHUF Jurnal Pengkajian Al-Qur'an Dan Budaya 11/1, (2018), 119-43.

Novanda, Galuh Dwi. “Advocacy and Legal Aid During Covid-19 Pandemic: How Indonesia Survives?” The Indonesian Journal of International Clinical Legal Education 2/2, (2020), 101-10.

O’Donnell, S Jonathon. "Islamophobic Conspiracism and Neoliberal Subjectivity: The Inassimilable Society." Patterns of Prejudice 52/1, (2018), 1-23. https://doi.org/10.1080/0031322X.2017.1414473.

Putra, Muhammad Yunan. "Talfiq Dan Pengaruhnya Terhadap Ibadah Masyarakat Awam Serta PandanganPandangan Ulama Fikıh.” SANGAJI:Jurnal Pemikiran Syariah Dan Hukum 2/1, (2018), 160-82.

Qotadah, Hudzaifah Achmad. "Covid-19: Prayers Performance of Medical Team Without Ablution And Tayammum Based On Four Madhab Fiqh.” SALAM: Jurnal Sosial Dan Budaya Syar-I 7/8, (2020a.).

-_-“Covid-19: Tinjauan Maqasıd Al-Sharıah Terhadap Penangguhan Pelaksanaan Ibadah Shalat Di Tempat Ibadah (Hifdz Al-Nafs Lebih Utama Dari Hifdz Al-Din?)." SALAM: Jurnal Sosial Dan Budaya Syar-I 7/7, (2020b).

Rahman, Z. "Mujahadah Al-Nafs among Covid 19 Patients in Quarantine." International Journal of Psychosocial Rehabilitation 24/1, (2020).

Rajab, Alif Jumai, Muhamad Saddam Nurdin, and Hayatullah Mubarak. "Tinjauan Hukum Islam Pada Edaran Pemerintah Dan MUI Dalam Menyikapi Wabah Covid-19.” BUSTANUL FUQAHA: Jurnal Bidang Hukum Islam $1 / 2,(2020), 156-73$.

Rifa'i, Ilyas, Ferli Septi Irwansyah, Mar'atus Sholihah, and Astri Yuliawati. "Dampak Dan Pencegahan Wabah Covid-19: Perspektif Sains Dan Islam.” Jurnal Lembaga Penelitian Dan Pengabdian Masyarakat (LP2M). (2020).

Rokib, Mohammad. "The Importance of Faith-Based Organization in Shaping Natural Disaster: Case Study of Muhammadiyah." SALAM Jurnal Study Masyarakat Islam, (2012).

Rusyana, Ayi Yunus, Dedi Supriyadi, Ali Khosim, and Fahmi Hasan Nugroho. "Fatwa Penyelenggaraan Ibadah Di Saat Pandemi Covid-19 Di Indonesia Dan Mesir.” Digital Library UIN Sunan Gunung Djati, (2020).

Saebani, Beni Ahmad, Mohammad Nadjib, Mustopa Kamal, and Yana Sutian. "Kesadaran Teologis Keberagamaan Umat Manusia Dalam Menghadapi Wabah Covid-19.” Digital Library UIN Sunan Gunung Djati Bandung, (2020).

Saefi, Muhammad, Ahmad Fauzi, Evi Kristiana, Widi Cahya Adi, M Muchson, M Eval Setiawan, Novita Nurul Islami, Dian Eka Aprilia Fitria Ningrum, M Alifudin Ikhsan, and Mavindra Ramadhani. "Survey Data of COVID-19-Related Knowledge, Attitude, and Practices among Indonesian Undergraduate Students." Data in Brief, 105855, (2020).

Salzberger, Bernd, Thomas Glück, and Boris Ehrenstein. "Successful Containment of COVID-19: The WHO-Report on the COVID-19 Outbreak in China." Infection, 2020. https://doi.org/10.1007/s15010-020-01409-4.

Sindre, Gyda M. "From Secessionism to Regionalism: Intra-Organizational Change and Ideological Moderation within Armed Secessionist Movements." Political Geography 64, (2018), 23-32. https://doi.org/https://doi.org/10.1016/j.polgeo.2018.02.004. 
Solahudin, Dindin, Dang Eif Saiful Amin, Deden Sumpena, and Fathin Anjani Hilman. “Analisis Kepemimpinan Di Indonesia Dalam Kerangka Tanggap-Darurat Covid-19.” Penulisan Karya Tulis Ilmiah UIN Sunan Gunung Djati Bandung Di Masa Work From Home Tahun 2020.

Stein, Richard Albert. "The 2019 Coronavirus: Learning Curves, Lessons, and the Weakest Link." International Journal of Clinical Practice, (2020). https://doi.org/10.1111/ijcp.13488.

Stratton, Samuel J. "COVID-19: Not a Simple Public Health Emergency." Prehospital and Disaster Medicine 35/2, (2020), 119-119. https://doi.org/10.1017/\$1049023X2000031X.

Suhendar, Dede, Asep Supriadin, Gina Giftia Azmiana Delilah, and Tety Sudiarti. n.d. "Potensi Mineral Tanah Liat--Surfaktan Untuk Aplikasi Bahan Sanitasi Dalam Pencegahan Covid-19: Pembelajaran Dari Taharah Yang Menggunakan Tanah." Article.

Suherdiana, Dadan, Aang Ridwan, Uwes Fatoni, and others. "Pesan Dakwah Ormas Islam Indonesia Dalam Menghadapi Krisis Keagamaan Masa Pandemi Covid-19.” Karya Tulis Ilmiah, 2020.

Syahnan, Mhd. "Nahdlatul Ulama Scholar In Mandallıng Land: A Biography of Shaykh Ali Hasan Ahmad AdDary." Journal of Contemporary Islam and Muslim Societies, (2019). https://doi.org/10.30821/jcims.v3i1.4138.

Syamsuddin, M. Din. "The Muhammadiyah Da'wah and Allocative Politics in the New Order Indonesia." Studia Islamika, (1995). https://doi.org/10.15408/sdi.v2i2.834.

Taqiyuddin, Muhammad. "Sample from Social Media (Sampel Dari Media Sosial)." Zenodo, 2020a. https://doi.org/10.5281/zenodo.3940717.

-_-“Sample from Social Organization and Government (Sampel Dari Organisasi Masyarakat Dan Negara)." (2020b). https://doi.org/10.5281/zenodo.3940736.

-_-“Sample from Websites (Sampel Dari Berita Website)." Zenodo, (2020c). https://doi.org/10.5281/zenodo.3940719.

Turpin, Merrill J., Miho Asano, and Marcia Finlayson. "Combining Qualitative and Quantitative Data Collection and Analysis Methods in Understanding Multiple Sclerosis Fatigue Management." International Journal of Qualitative Methods, (2015). https://doi.org/10.1177/160940691501400206.

Yono, Yono. “Sikap Manusia Beriman Menghadapi Covid 19.” Mizan:Journal of Islamic Law 4/1, 2020.

Yono, Yono, Indriya Rusmana, and Hielda Noviyanty. "Psikoterapi Spiritual Dan Pendidikan Islam Dalam Mengatasi Dan Menghadapi Gangguan Anciety Disorder Di Saat Dan Pasca Covid 19." SALAM: Jurnal Sosial Dan Budaya Syar-I 7/8, (2020).

Zahrotunnimah, Zahrotunnimah. "Langkah Taktis Pemerintah Daerah Dalam Pencegahan Penyebaran Virus Corona Covid-19 Di Indonesia." SALAM: Jurnal Sosial Dan Budaya Syar-I 7/3, (2020), 247-60.

Zarkasyi, Hamid Fahmy. "The Rise of Islamic Religious-Political Movements in Indonesia: The Background, Present Situation and Future." Journal of Indonesian Islam 2/2, (2008), 336-78.

-_-“Epistemological Implication of Al-Ghazzali's Account of Causality." Intellectual Discourse 26/1, 2018, 51-73.

-_- Appraising the Moderation Indonesian Muslims with Special Reference to Muhammadiyah and Nahdlatul Ulama." ADDIN 12/1, (2019), 1. https://doi.org/10.21043/addin.v12i1.4179. 